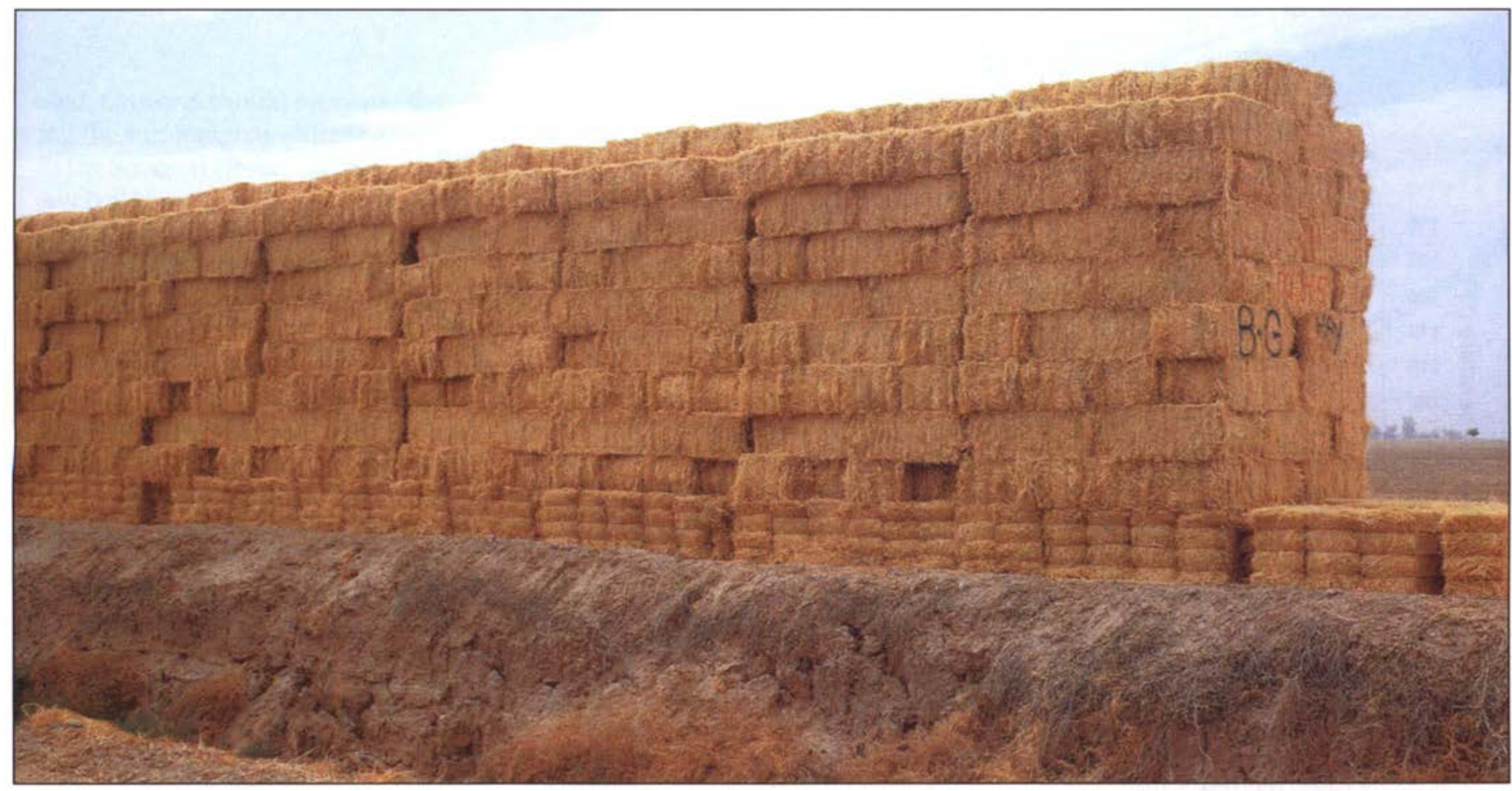

\title{
Desert heat degrades quality of stored alfalfa hay
}

Hay producers in the irrigated Sonoran Desert normally store hay unprotected alongside ditch banks.
Juan N. Guerrero

To quantify the effects of summertime heat on baled alfalfa hay, we baled alfalfa in May 1993 in three areas of the irrigated Sonoran Desert and stored it for $\mathbf{2 0}$ weeks. At each site we subjected the bales to four different storage treatments: an air-conditioned room, unprotected in full sunlight, in full sunlight but covered with a plastic tarp, and under a roof. Temperatures of the bales stored in full sunlight, whether tarped or unprotected, often exceeded $120^{\circ} \mathrm{F}$ for extended periods of time. After 20 weeks, feed quality of the bales stored in full sunlight decreased more than the quality of the shaded bales and those kept in an air-conditioned room. Bales stored unprotected in full sunlight dried out excessively and became brittle. Protected from the scant summer rainfall, the tarpcovered bales did not bleach and were able to maintain moisture for a longer period of time. Among the three outdoor treatments, nutritive quality of alfalfa hay bales was best preserved by storage under a protective roof.

The Sonoran Desert extends from northwestern Mexico into southeastern California and southwestern Arizona. During the summer, daytime temperatures exceeding $110^{\circ} \mathrm{F}$ are common. About 400,000 acres of irrigated alfalfa, primarily for nearby dairies, are grown in the region during a continuous growing season. Mean annual precipitation in the Imperial Valley (in the central Sonoran Desert) is 2.94 inches. Due to the lack of rainfall in the Sonoran Desert, baled alfalfa hay is generally stored in uncovered stacks along roadsides.

Processed foodstuffs stored for long periods of time can suffer heat damage and may contain Maillard polymers, also known as nonenzymatic "brown- ing" reactions. Maillard polymers occur when sugar residues condense with amino acids, then polymerize, forming a brown substance containing about $11 \%$ nitrogen $(\mathrm{N})$. These heatdamaged foodstuffs are characterized by a light-yellow to dark-brown discoloration.

Maillard polymers may be found in ensiled forages that have been exposed to air and heated due to aerobic fermentation. Hay baled with excessive moisture often ferments and heats by a similar mechanism. If stored alfalfa hay heats higher than $100^{\circ} \mathrm{F}$, the Maillard reaction - which is influenced by moisture content and time can occur to a measurable extent. The extent of heat damage caused by the formation of Maillard polymers can be quantified by measuring the nitrogen content in the acid detergent fiber residue. Maillard polymers in heatdamaged forages are largely indigestible by ruminants, with the digestible portion generally excreted intact in the urine. If proteins in alfalfa hay are 


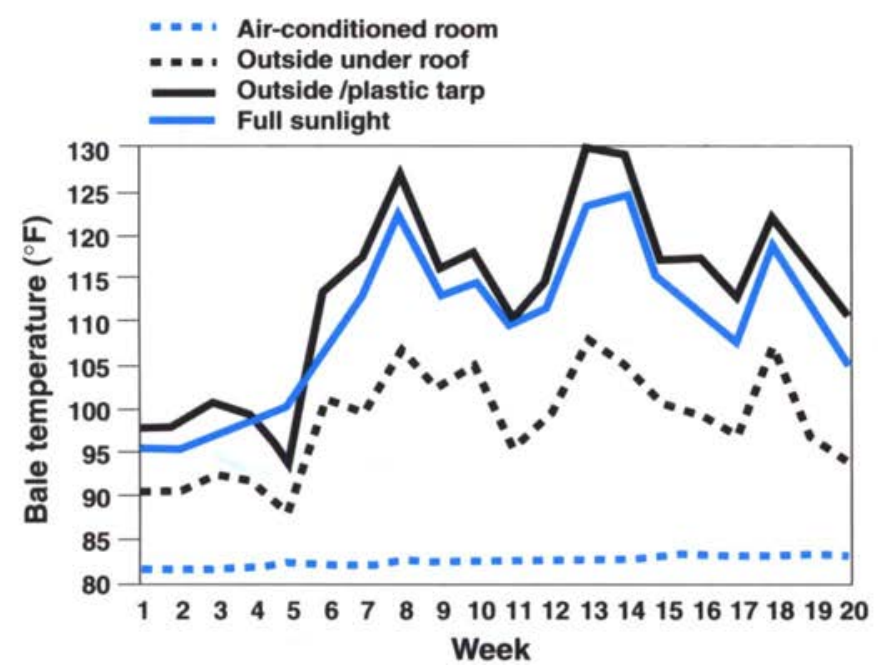

Fig. 1. Mean bale temperatures of alfalfa stored from May to October 1993 in the Sonoran Desert under four treatments.

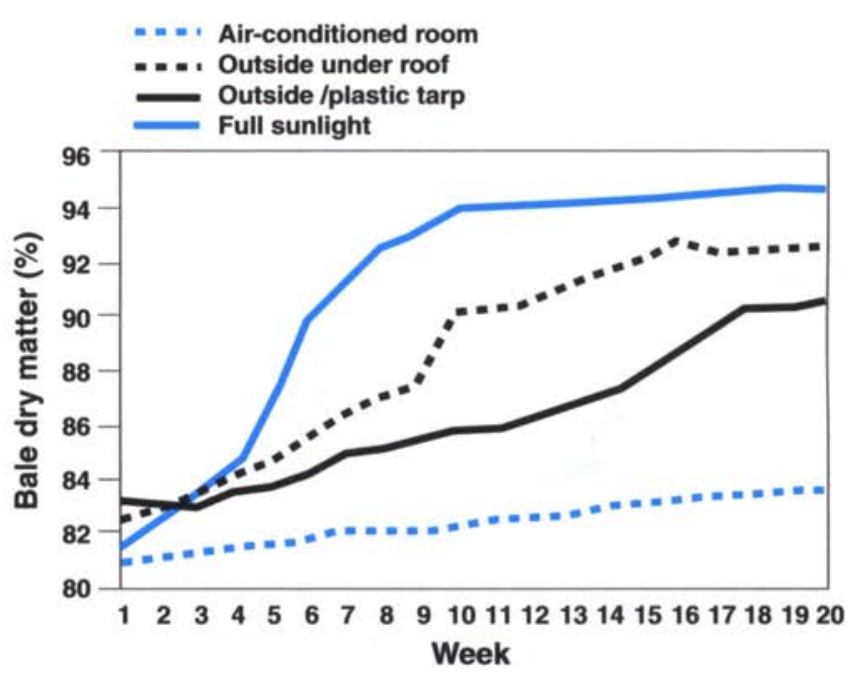

Fig. 2. Mean bale dry matter from alfalfa stored from May to October 1993 in the Sonoran Desert under four treatments. damaged by heat, the hay's nutritive value decreases. The objective of this study was to quantify the effects of heat on spring-baled alfalfa hay.

\section{Four hay-storage treatments}

We baled alfalfa hay at three locations in the irrigated Sonoran Desert in May 1993: (1) the UC Desert Research and Extension Center, 7 miles east of El Centro (just north of the Mexican border), (2) the Colorado River Indian Reservation, 30 miles south of Parker, Ariz., and 150 miles northeast of El Centro, and (3) the Autonomous University of Baja California agriculture school, southeast of Mexicali, Mexico, and 75 miles southeast of El Centro. The third cuttings of second-year stands of 'CUF101' alfalfa were baled. The alfalfa was swathed at about the $10 \%$ bloom stage of growth. Our objective was to bale the alfalfa hay at $15 \%$ to $17 \%$ windrow moisture.

Hay bales were randomly allocated for 20-week storage periods under four treatments at each location: (1) an air-conditioned room maintained at $80^{\circ} \mathrm{F}$ constant temperature (COOL), (2) unprotected roadside storage in full sunlight (SUN), (3) roadside storage protected from sun and precipitation by a 6-mil, gray plastic tarp (TARP), and (4) outside under a roof, in a building open on two sides to protect the bales from sunlight and precipitation (SHADE). Bales were stacked four high with 40 to 60 bales per treatment at each location.

We recorded temperature, precipitation, relative humidity and solar radiation daily, and calculated weekly minimum, maximum and mean temperatures, and relative humidity values. Each week, four random hay samples from each treatment and each location were combined for quality analyses. On each hay sampling date at about 3 P.M., we recorded the corresponding bale temperature and moisture using an 18-inch commercial spear probe. Each alfalfa hay sample was analyzed for dry matter (DM), crude protein (CP), ash, neutral detergent fiber (NDF), acid detergent fiber residue (ADF), acid detergent lignin $(\mathrm{ADL})$ and acid detergent insoluble nitrogen (ADIN).

Analyses of variance were used to determine the differences between treatments for the chemical components of the hay. ADIN, ADIN/N, NDF, ADF, ADL, bale DM and bale temperature were the dependent variables in the statistical model. The experimental units were weekly composite hay samples from each treatment and location. Location, treatment, location $x$ treatment, week, location $x$ week, treatment $x$ week and location $x$ treatment $x$ week were the independent variables in the statistical model. Location was treated as a random variable.

\section{Bale temperatures and dry matter}

From May through October, longterm mean, monthly, maximum temperatures in the Sonoran Desert are $96.5^{\circ}, 106^{\circ}, 109^{\circ}, 107^{\circ}, 103^{\circ}$ and $94^{\circ} \mathrm{F}$, respectively. The SUN and TARP bales heated to more than $120^{\circ} \mathrm{F}$ for about 6 weeks (fig. 1) and reached more than $110^{\circ} \mathrm{F}$ for 12 weeks. The SHADE bales were consistently cooler than the bales exposed to sunlight. The SHADE bales heated to $105^{\circ} \mathrm{F}$ for 3 weeks and to $100^{\circ} \mathrm{F}$ for 9 weeks. The COOL bales, in an air-conditioned room throughout the trial, maintained a constant $82^{\circ} \mathrm{F}$ temperature.

Initial moisture of all experimental bales was $16 \%$ to $18.5 \%$. Over the 20 week trial period the COOL bales dried only 2 to 3 percentage units (fig. 2). After 10 weeks, the SHADE bales had dried to $90 \% \mathrm{DM}$ and to $92 \% \mathrm{DM}$ at 20 weeks. After 6 weeks the SUN bales had dried to $90 \%$ DM and to $95 \%$ DM at 20 weeks. The plastic tarp maintained more moisture in the alfalfa bales during the hot, dry desert summer, drying to only $90 \% \mathrm{DM}$ after 20 weeks of storage. The surface of the SUN bales was bleached whereas the surface of the SUN and TARP bales lost leaves. At $95 \%$ DM the alfalfa hay of the SUN bales was brittle.

When dry, brittle hay is chopped or ground in cattle diets, it becomes dusty and unwanted "fines" are cre- 
ated. Growers should be aware that during the summer, hay stored unprotected in the Sonoran Desert can become excessively dry, reducing yield. Dry, brittle hay is also unsuitable for compression into metal containers for export.

\section{Insoluble nitrogen}

The term ADIN/N refers to the fraction of nitrogen in $\mathrm{ADF}$ as a portion of total nitrogen. The ADIN/N fraction represents the portion of crude protein (CP) that is heat-damaged and therefore indigestible by ruminants. For alfalfa, more than $14 \%$ ADIN/N indicates heat-damaged hay. The initial ADIN/ $\mathrm{N}$ values for the experimental bales were $8 \%$. Bale storage treatments affected $(P<.01)$ ADIN / N levels in our trial hays. By the end of the 20-week trial period, ADIN/N for the COOL bales had increased to $10.9 \%$, SHADE bales to $14.1 \%$, SUN bales to $23.3 \%$ and TARP bales to $24.1 \%$ (fig. 3 ).

In this study, mean weekly maximum temperatures were consistently greater than $100^{\circ} \mathrm{F}$ from the end of May until the end of the trial in midOctober. In general, alfalfa hay stocked on roadsides in the Sonoran Desert during the summer, whether tarped or not, decreased in protein quality. Since ADIN/N and overall alfalfa hay digestibility are negatively correlated in ruminants, the detrimental effects of heat-damage are further accentuated. For alfalfa hay stacked during the summer in the Sonoran Desert, the SHADE treatment has promise to keep the rate of increase of ADIN/N at an acceptable level.

Since visual appraisal cannot quantify decreased hay quality caused by lengthy storage periods, the results of this study suggest that hay should be analyzed prior to feeding rather than after removal from the field. The inclusion of ADIN in routine chemical hay analyses, as well as DM, CP, NDF and ADF for hay that apparently has been stored for extended summer periods, would be justified.

\section{Fiber levels}

In ruminants, the NDF content of a forage is negatively correlated to voluntary intake, while the ADF content is negatively correlated to its digest- ibility. The energy value of alfalfa hay is often estimated from the ADF level. The higher the voluntary intake by a ruminant, the more that the animal will produce, either as body-weight gain or milk output.

Bale storage treatments affected NDF and ADF levels of our trial hays $(P<.01)$. Over the trial period, COOL NDF increased from $50.3 \%$ to $51.5 \%$, SHADE from $50.2 \%$ to $52.2 \%$, SUN from $50.2 \%$ to $54.6 \%$ and TARP from $50.3 \%$ to $55.1 \%$ (fig. 4 ). Over the trial period, COOL ADF increased from $28.4 \%$ to $29.7 \%$, SHADE from $28.4 \%$ to $30.7 \%$, SUN from $28.5 \%$ to $33.5 \%$ and TARP from $28.5 \%$ to $33.6 \%$ (fig. 5 ). These chemical analyses indicate that SUN- and TARP-treated hays have less economic value than hay stored under shade structures during the summer in the Sonoran Desert.

\section{Exposure hurts hay quality}

Storing alfalfa hay outdoors in the Sonoran Desert for extended summer periods increased the levels of neutral detergent fiber (NDF), acid detergent fiber residue (ADF) and acid detergent insoluble nitrogen percentage of total nitrogen (ADIN/N), resulting in negative effects on nutritional quality. Alfalfa hay stored on roadsides, whether tarped or not, and heated for extended periods of time, had the greatest reductions in nutritive quality. Storing hay under tarps slowed the drying of hay and maintained higher moisture levels. Of the three outdoor storage methods evaluated in this study, the roof-covered hay, where no sunlight touched the hay, was the method that best preserved alfalfa-hay quality.

J.N. Guerrero is Area Livestock Advisor for Imperial and Riverside counties, UC Cooperative Extension, located at the Desert Research and Extension Center; and S.S. Winans is County Director, University of Arizona Cooperative Extension, La Paz County.

The authors wish to thank Julio Meza and Debbie Esquerra for assistance with data compilation and laboratory analyses; and Charlie Chávez of the Colorado River Farms, and the Autonomous University of Baja California, Mexico, for their contributions to this study.

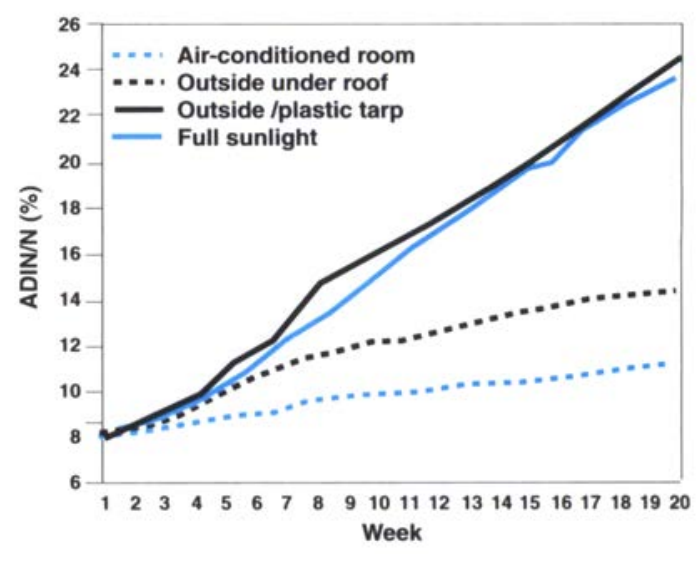

Fig. 3. Mean acid detergent insoluble nitrogen/ nitrogen values of alfalfa stored from May to October 1993 in the Sonoran Desert under four treatments.

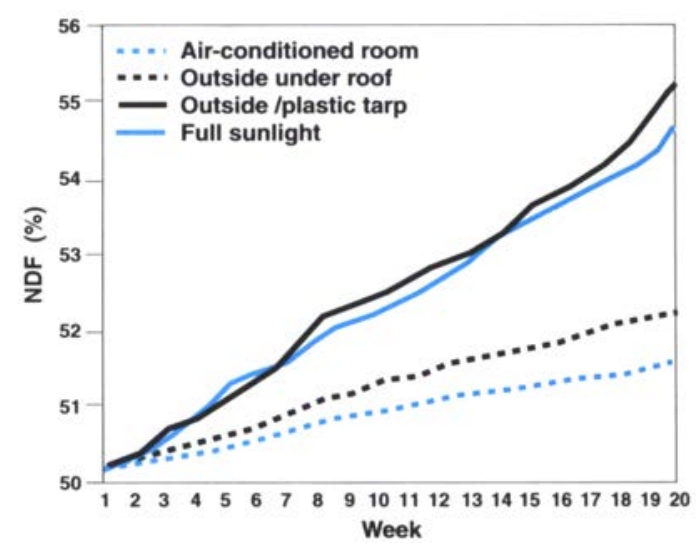

Fig. 4. Mean neutral detergent fiber values of alfalfa stored from May to October 1993 in the Sonoran Desert under four treatments.

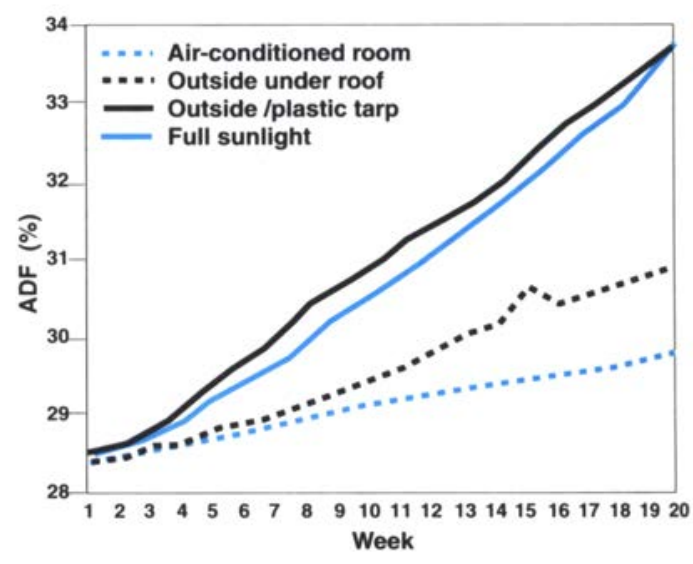

Fig. 5 Mean acid detergent fiber residue values of alfalfa stored from May to October 1993 in the Sonoran Desert under four treatments. 


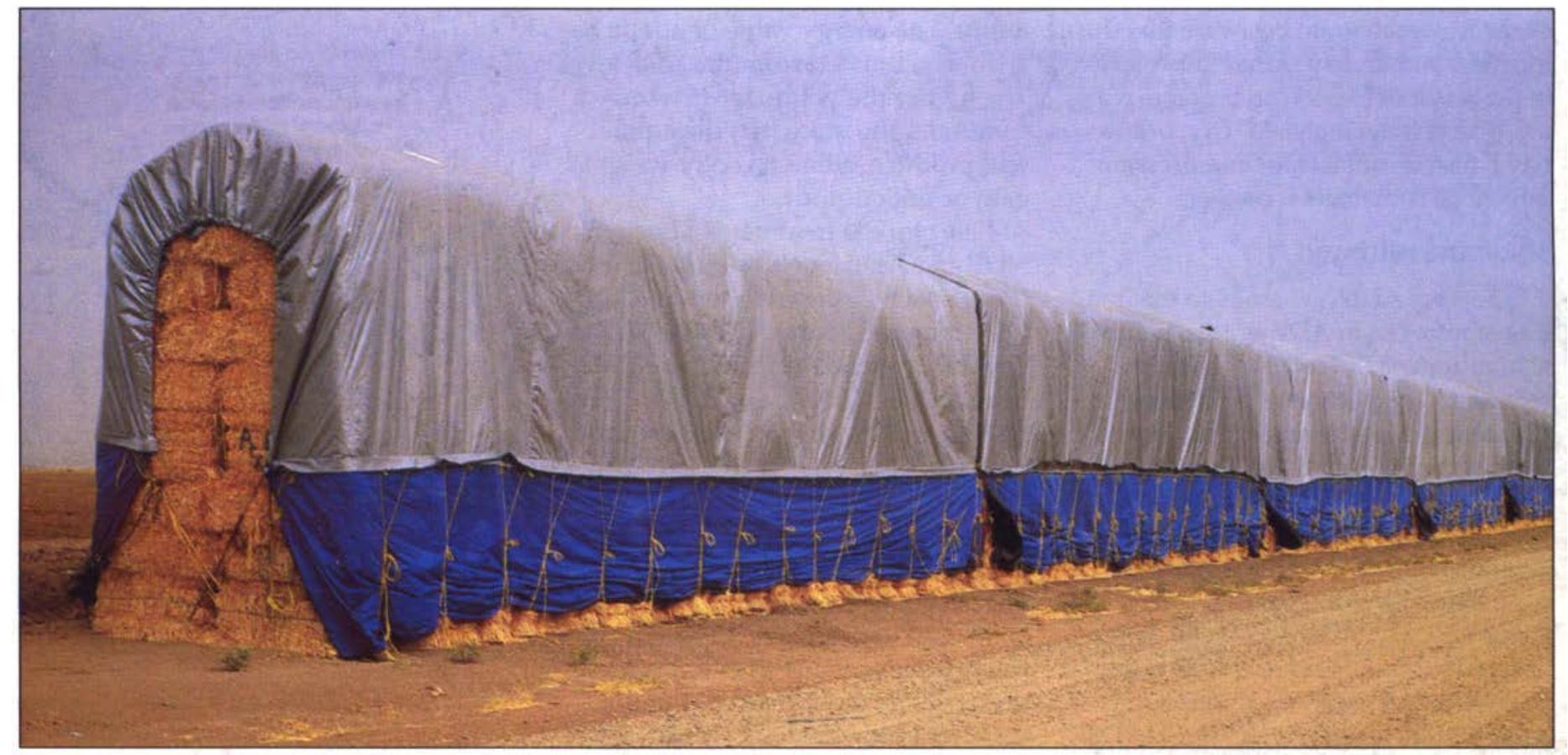

\section{Further reading}

Bath DL, Marble VL. 1989. Testing alfalfa for its feeding value. Leaflet 21457. UCCE. Davis.

Guerrero JN, Winans SS. 1997. Summertime storage of alfalfa hay in the irrigated Sonoran Desert affects hay quality. J Prod Agri 10:495-501.

Pitt RE. 1990. Silage and hay preservation. NRAES-5. NE Reg Agri Eng Serv. Ithaca, NY.

Rotz CA, Muck RE. 1994. Changes in forage quality during harvest and storage. In: Fahey GC (ed). Forage Quality, Evaluation, and Utilization. Madison, WI: Am Soc Agron. p 828-68.

Thomas JW, Yu Y, Middleton T, Stallings C. 1982. Estimations of protein damage. In: Owens FN (ed), Protein Requirements for Cattle, Proc. Stillwater, OK. Nov. 19-21,

1980. Okla. State Univ. MP 109. Stillwater, OK. p 81-98.

A To protect hay from rain damage and from excess bleaching, some hay producers store hay protected from the elements by a plastic tarp alongside ditch banks.

$\checkmark$ Another method to protect hay from the elements is to put the hay under a roof.

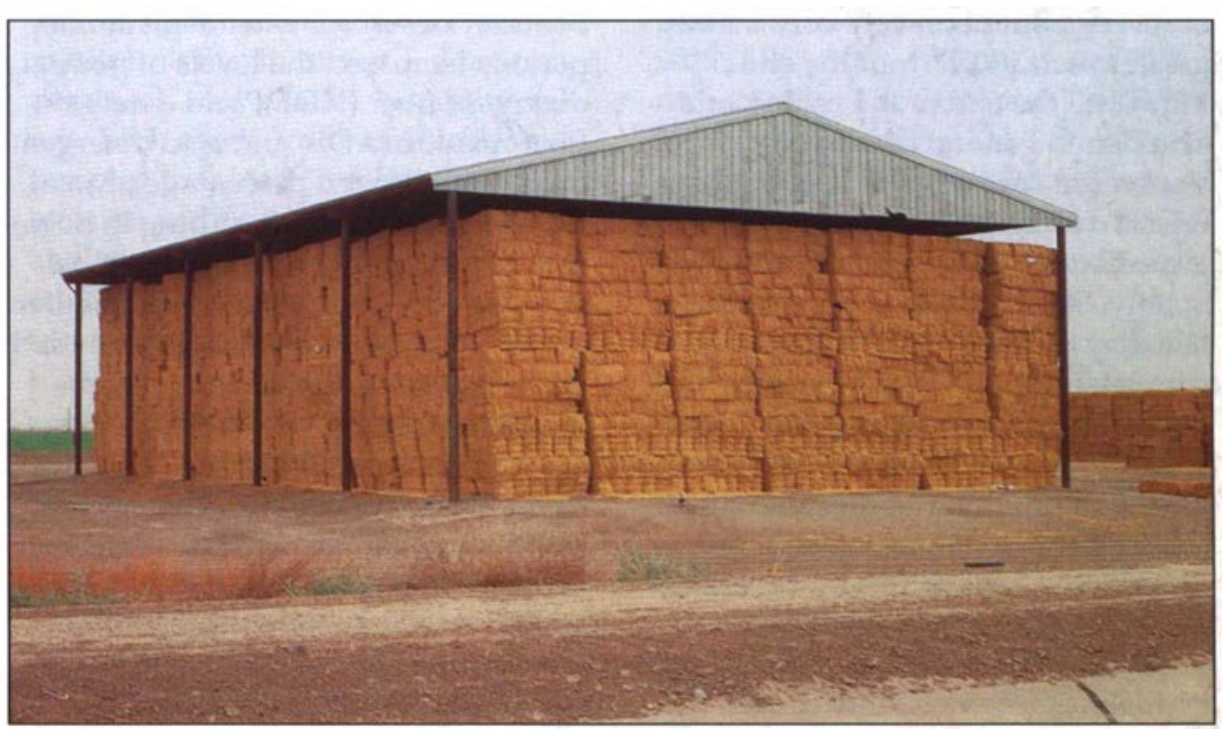

\section{CALIFORNIA AGRICULTURE ASSOCIATE EDITORS}

Animal, Avian, Aquaculture
\& Veterinary Sciences
Jim Cullor
Christopher M. Dewees
Bennie I. Osburn
Kathryn Radke
Barbara A. Reed
Economics \& Public Policy
George Goldman
Richard A. Howitt
Alvin Sokolow

Food \& Nutrition

Barbara Schneeman Eunice Williamson

\section{Human \& Community} Development

Linda M. Manton

Karen P. Varcoe

Land, Air \& Water Sciences John Letey

Henry J. Vaux, Jr.
Natural Resources Daniel W. Anderson Lynn Huntsinger Richard B. Standiford

Pest Management Michael K. Rust Robert Washino

\section{Plant Sciences} Jodie S. Holt

Lee F. Jackson

G. Steven Sibbett http://danr.ucop.edu/calag/

CALAG@ucop.edu

PH: 510 987-0044

FAX: $510465-2659$ 